Jurnal Bimbingan Konseling
$10(2)(2021): 99-105$
UNNES

\title{
The Effectiveness of Group Guidance with Cinematherapy and Role- Playing Techniques to Improve Prosocial Behavior
}

\author{
Intan Herfidawati ${ }^{1 凶}$, Mungin Eddi Wibowo ${ }^{2}$, Edy Purwanto ${ }^{2}$ \\ ${ }^{1}$ Universitas PGRI Semarang, Semarang, Indonesia \\ 2. Pascasarjana Universitas Negeri Semarang, Indonesia
}

\begin{abstract}
Article Info
History Articles

Received:

5 Mei 2021

Accepted:

20 June 2021

Published:

30 August 2021

Keywords:

Cinematherapy,

Group Guidance,

Role Playing,

Prosocial Behavior

Abstract

Prosocial development is strongly related to various positive development for students, including academic success, personal achievement, positive relationship with others, and higher social competence. However, some adolescents remain doing antisocial behavior. Thus, this study attempted to examine the effectiveness of a group guidance service with cinematherapy, role playing, and the combination of cinematherapy and role-playing techniques to improve the prosocial behavior of Vocational High School (SMK) students. To do so, it used an experimental design of Randomized Pretest-Posttest Comparison Group by involving 30 students divided into three groups with 10 students in each. Based on Wilcoxon test results, the guidance group with both cinematherapy and role-playing techniques was effective to improve prosocial behavior indicated by the results of $(Z=2.81, \mathrm{p}<0.05)$ for cinematherapy, and $(\mathrm{Z}=2.81, \mathrm{p}<0.05)$ for role playing. In the same way, the combination of both techniques was effective to improve prosocial behavior by gaining $(Z=2.81$, $\mathrm{p}<0.05$ ). Additionally, the results of Kruskal Wallis test showed no significant difference in the level of effectiveness of the group with cinematherapy, role playing, and the combination of both techniques, namely ( $x 2=0.23, p>0.05)$. These findings are expected to encourage counselors to conduct group guidance with cinematherapy and role-playing techniques to improve prosocial behavior.
\end{abstract}

Correspondence address:

Campus UNNES Kelud Utara III, Semarang, 50237

E-mail: intan191091@gmail.com 


\section{INTRODUCTION}

Prosocial behavior holds an important role for Vocational High School (SMK) students because basically humans need other beings and cannot live alone, so they will relate to each other and environment. Adolescents at school age start to join peer groups, make friends, practice the attitude of helping, affection, and give attention to one another (Jauhari, 2018). Prosocial behavior is one of social competencies to own by adolescents since it is the key to a social competence that can encourage positive social interactions among them (Padilla-Walker, Fraser, Black, \& Bean, 2014). Adolescents' prosocial behavior can be realized directly (encouraging one another to do prosocial behavior) and indirectly (in form of group norms, hopes, or friendship) (Erreygers, et al, 2018).

Penner (in Quain, 2016) states that prosocial behavior is strongly related to various positive development of adolescents, including academic success, personal achievement, positive relationship with others, and higher social competence. It is influenced by internal and external factors, such as others attendance, sacrifice, stimulus, social norms, the relationship between the helpers and one being helped, and mood (Yusuf \& Kristiana, 2017). In terms of education, prosocial behavior deals with establishing and maintaining good relationships by helping teachers or peers in school environment and practicing this behavior in classroom (Moreno in Akbar and Listiara, 2012).

Prosocial behavior as a voluntary action is done with the aim of benefiting others. It can be realized in a form of generous selfless acts to help someone (Stang in Iqbal, 2013). The emergence of prosocial behavior such as sharing, helping or assisting, caring and feeling empathy with others and the needs or requests of others will make someone become an adolescent who is liked by his friends and excels academically.

Albert \& Thilagavathy (2013) consider prosocial behavior as a voluntary act attempted to advantage others or society. In addition,
Afolabi (2014) explains that prosocial behavior is an act done or planned to help others with no motive. This is supported by Eisenberg, Fabes \& Sprinrad (in Berk, 2012), amely prosocial or altruistic behavior is an action that benefits others without the hope of getting a reward.

A study by Wang, Wang, Deng, \& Chen (2019) found that empathetic children are more liked by their friends due to their higher prosocial behavior, while those whose aggression is high are less liked. In other words, prosocial behavior is an important requirement for peer's acceptance. Kau (in Rachman \& Nashori, 2016) argues that the phenomenon of prosocial behavior decline in adolescent can be seen from the low sense of helping, sharing, and cooperation with peers, elders, or society. This can cause adolescents to become more individualistic for in a long term. They will prefer doing antisocial behavior to prosocial one.

It is important to improve adolescents prosocial behavior so that they can have social skills to live in society. Putra, Gustituati, \& Syahniar (2015:32) state that the success of adolescents in completing developmental tasks leads them into a good prosocial condition where they can feel happy, harmonious, and become productive people. On the other hand, if it fails, the adolescents will experience unhappiness or difficulty in their life.

Esgi \& Esti (2018) in their study mention that a group guidance service is effective to direct students' behavior change. It is supported by a study by Puspita, Mulawarman, \& Awalya (2020) which proved that group guidance through role playing technique is effective to improve empathy and responsibility skills, whereas empathy itself motivates prosocial behavior in various situations (Hoffman in Vaish, 2019).

Trifiana's study (2015) shows that students' low prosocial behavior can be handled by Guidance and Counseling teachers by giving a group guidance service. According to Wibowo (in Rini \& Sugiharto, 2017) group guidance is realized in group activities in which the leader of the group provides information and directs his group discussion so that the members will be 
more social or get some help to achieve common goals. Moreover, according to Wulandari, Dharmayana, \& Afriyati (2018) group guidance services can take advantage of group dynamics as the social development of students in collaborating, sharing, helping each other, caring for others and being able to consider the rights and welfare of others. This social development means is in accordance with prosocial behavior, namely helping, sharing, cooperation, empathy and honesty (Hikma et al, 2018). This elaboration shows that prosocial behavior can be improved by using techniques.

Some studies have proved that cinematherapy technique is effective to cope with individual behavioral problems. Through film, people can learn changing unwanted behavior into the desirable one (Solomon in Suwanto \& Nisa, 2017). By watching a film, students will know actors and their characters which shape the theme of the film and apply them to students as a therapy (Juliantika \& Kusumadewi, 2017). A study by Niva (2016) proved that cinematherapy approach can improve students' prosocial behavior. It is strengthened by Fisnawati (2012) who found that higher intensity of watching will contribute greater tendency of prosocial behavior to adolescents.

Furthermore, other studies have proved role playing technique can improve prosocial behavior. According to Awlawi (2013) role playing is a technique in a group approach that is applicable for psychotherapy or counseling. Similarly, a study by Greitemeyer \& Mügge (2014) revealed that violence increases aggressive behavior, cognition, and reduces prosocial behavior and influence, whereas prosocial play reduces cognitive aggressive behavior and improves prosocial behavior. There is also a study conducted by Putra, Wibowo, \& Sugiharto (2019) which found the implementation of group guidance with Desa Bahagia role play is effective to improve students' prosocial behavior.

Given the explanation, the current study attempted to examine the effectiveness of group guidance with cinematherapy and role-playing techniques to improve the prosocial behavior of SMK students. It is expected that the findings of this study can be a recommendation in the implementation of group guidance, especially in the social field.

\section{METHOD}

Randomized pretest-posttest comparison group design was employed in this experimental study. Meanwhile, the population was the students of grade XI and XII as many as 169 students. Of those number, 30 were chosen based on their low scores and grouped into three (each consisted of 10 students), namely group with cinematherapy technique, group with role playing technique, and the rest was group with the combination of cinematherapy and roleplaying techniques.

To obtain the data of students' prosocial behavior, the researchers used Prosocial Tendencies Measure (PTM) adopted instrument designed by Carlo \& Randall (2002) with $\sum 23$ items and $\sum 1-5$ scale. This instrument was developed based on six prosocial behavior components, namely anonymous, public, altruism, emotional, compliant, and dire with the reliability of cornbach alpha coefficient of 0.805 .

This study used quantitative approach with experimental design. The experiment was realized by the randomized comparison group based on pretest-posttest scores of the three previously mentioned groups with several procedures. First, the researchers gave pretest to all three groups to determine the initial condition of students' prosocial behavior. Second, interventions in form of cinematherapy, role playing, and the combination of cinematherapy and role-playing techniques were given for five sessions with the time allotment of $2 \times 45$ minutes for each. Third, the researchers gave posttest to all groups to examine the latest condition of their prosocial behavior.

\section{RESULTS AND DISCUSSION}


After the treatment, the mean and standard deviation of all groups increased. In details, the cinematherapy group gained the pretest score of $(\mathrm{M}=46.6 ; \mathrm{SD}=3.27)$, while the posttest was $(\mathrm{M}=71.8 ; \mathrm{SD}=10.14)$, the roleplaying group pretest score was $(\mathrm{M}=47.1$;
$\mathrm{SD}=2.68)$, while its posttest scored $(\mathrm{M}=73.4$; $\mathrm{SD}=9.41)$. Similarly, the combination of cinematherapy and role-playing techniques experienced an increase in the average and standard deviation of pretest $(\mathrm{M}=46.2$; $\mathrm{SD}=2.78)$ to posttest $(\mathrm{M}=73.7 ; \mathrm{SD}=7.81)$.

Table. Wilcoxon and Kruskal Wallis Tests

\begin{tabular}{llllllll} 
& $\mathrm{N}$ & Pretest & \multicolumn{3}{c}{ Posttest } & $\mathrm{Z}$ & $\mathrm{P}$ \\
& & $\mathrm{M}$ & $\mathrm{SD}$ & $\mathrm{M}$ & $\mathrm{SD}$ & & \\
\hline Cinematherapy & 10 & 46.6 & 3.27 & 71.8 & 10.14 & $-2.81^{\mathrm{b}}$ & $<0.05$ \\
Role Playing & 10 & 47.1 & 2.68 & 73.4 & 9.41 & $-2.81^{\mathrm{b}}$ & $<0.05$ \\
Cinematherapy \& Role Playing & 10 & 46.2 & 2.78 & 73.7 & 7.81 & $-2.81^{\mathrm{b}}$ & $<0.05$ \\
\hline $\mathrm{X}^{2}$ & & 0,21 & \multicolumn{5}{c}{0,23} \\
$\mathrm{P}$ & & 0,901 & & 0,893 & & \\
\hline
\end{tabular}

The table above shows that the techniques implemented in the three groups were effective to improve prosocial behavior, namely cinematherapy technique $(Z=-2.81, p<0.05)$, role playing technique $(\mathrm{Z}=-2.81, \mathrm{p}<0.05)$, and the combination of cinematherapy and roleplaying techniques $(\mathrm{Z}=-2.81, \mathrm{p}<0.05)$.

Based on kruskal wallis test, there has been no difference in the results of group guidance effectiveness between cinematherapy technique, role playing technique, and the combination of cinematherapy and role-playing technique, namely $(p>0.05)$ or all interventions shared the equal effectiveness level.

What was found in this study is in line with a study by Tarmizi, Sugiharto \& Sutoyo (2020) who conducted a study on the effectiveness of group counseling using selfmanagement and cognitive restructuring techniques to reduce students' aggressive behavior. They found that all techniques are effective to reduce students' aggressiveness, but further analysis using Kruskal-wallis test infers no difference in the effectiveness of selfmanagement and cognitive restructuring technique.

Furthermore, the findings of this study indicated that the group guidance with cinematherapy and role-playing techniques was effective to improve the prosocial behavior of SMK Islam Media Bantarbolang students. This guidance was given to those who's prosocial behavior was low and resulted theoretically significant contribution, especially in the field of guidance and counseling with the combination of cinematherapy and role-playing techniques.

A study by Sari \& Lianawati (2020) supports the findings of this study in the way cinematherapy can improve students' prosocial behavior using a group guidance service indicated by the observation results after the treatment showing the samples have social empathy in classroom while previously did not.

Cinematherapy technique helps counselees to directly see how individuals socialize through the examples given by models. This technique improves students' prosocial behavior by giving behavioral models through messages containing in films through scenes played by the actors and the plot. Therefore, students have experiences to learn these new behavioral models.

Another study supporting the current study findings is from Mirnawati's (2020). Her study found some improvement of children prosocial behavior during the implementation of role playing. Thus, role playing is effective to improve prosocial behavior. Role playing technique is a learning strategy which uses the concept of roles, develop skills, and understanding relationship among humans by 
recognizing different roles and comparing one's behavioral perspective to the others.

The combination of cinematherapy and role-playing techniques can also be used in a group guidance service. Cinematherapy is a strategy to change negative behavior to positive one with the medium of movie or film which will stimulate counselees or clients to imagine and relax. The greater impression of a scene, the more memorable the clients will be so that there is a tendency for the audience to imitate the scenes watched in real life. Meanwhile, role playing is a technique where students will play a role and directly understand their role and how to behave and behave well, so students will automatically improve their abilities in social life in naturally and healthily. Therefore, a combination of these techniques can be an alternative to improve students' prosocial behavior at school.

\section{CONCLUSION}

According to the findings of this study, it can be concluded that a group guidance service with cinematherapy techniques and role-playing techniques is effective to improve students' prosocial behavior.

By referring to the conclusion above, it is suggested that counselors should use a group guidance service with cinematherapy and roleplaying techniques to improve students' prosocial behavior.

In addition, this study provides suggestions to related parties, namely (1) to add a control group as a comparison and plan the need for further action or follow-up in monitoring the impact of the intervention on the duration of the improvement of students' prosocial behavior because the use of this intervention was only measured through the results of the pretest and posttest, (2) to consider the duration of time for treatment.

\section{REFRENCES}

Afolabi, O. A. 2014. Psychosocial Predictors of Prosocial Behaviour Among a Sample of
Nigerian Undergraduates. European Scientific Journal, 10(2): 241-266. DOI: 10.19044/esj.2014.v10n2p\%p.

Akbar, Z. Y., \& Listiara, A. 2012. The Difference Between the Prosocial Tendency Regular Classes and Special Classes at SMAN 1 And SMAN 3k Semarang. Jurnal Psikologi Empati: Jurnal Karya Ilmiah S1 Undip, 1(1): 120-138. Retrieved From https://ejournal3.undip.ac.id/index.p $\mathrm{hp} /$ empati/article/view/438.

Albert, A. P., \& Thilagavathy, T. 2013. A Study on Pro Social Behaviour and Parental Behaviour of Higger Secondary Students. International Journal of Science and Research (IJSR). 2(11): 261-263. Retrieved From https://www.semanticscholar.org/pa per/A-Study-on-Pro-Social-

Behaviour-and-Parental-of-AlbertThilagavathy/bc25315c6b81782b00d 635743f484f30c1c062b5.

Awlawi, A. H. 2013. Teknik Bermain Peran Pada Layanan Bimbingan Kelompok Untuk Meningkatkan Sself Esteem. Jurnal Ilmiah Konseling, 2(1): 182-190. DOI: https://doi.org/10.24036/020132188 7-0-00.

Berk, E. L. 2012. Development Through the Lifespan. Alih Bahasa: Daryanto. Yogjakarta: Pustaka Pelajar.

Esgi, S., \& Esgi, N. 2018. The Effect of Group Guidancce Activities in Inappropriate Student Behaviors. European Journal of Education Studies, 4(2): 82-89. DOI: $10.5281 /$ zenodo. 1168780

Erreygers, S., Vandebosch, H., Vranjes, I., Baillien, E., \& Witte, H. D. 2018. Development of a Measure of Adolescents' Online Prosocial Behavior. Journal of Children and Media, 12(4): 1-17. doi.org/10.1080/17482798.2018.1431558

Fisnawati, A. 2012. Hubungan Antara Intensitas Menonton Reality Show Dengan Kecenderungan Perilaku Prososial Pada Remaja. EMPATHY Jurnal Fakultas Psikologi, 1(2):47-58. Retrieved from: 
https://garuda.ristekbrin.go.id/docu ments/detail/315438.

Greitemeyer, T., \& Mügge, D. O. 2014. Video Games Do Affect Social Outcomes: A Meta-Analytic Review of the Effects of Violent and Prosocial Video Game Play. Personality and Sosial Psychology Bulletin, 40(5): $\quad$ 578-589.

10.1177/0146167213520459.

Hikma., Munir, A., \& Munifah. 2018. Meningkatkan Perilaku Prososial Melalui Teknik Sosiodrama Pada Siswa Kelas VII H Smp Negeri 3 Palu. Jurnal Konseling dan Psikoedukasi, 3(1): 88-89. DOI: http://dx.doi.org/10.22487/jkp.v3i1. 10983

Iqbal, F. 2013. Prosocial Behavior in Different Situations among Men and Women. IOSR Journal Of Humanities And Social Science (IOSR-JHSS), $\quad 8(6): \quad 31-40$. Retrieved Form http://www.iosrjournals.org/iosrjhss/papers/Vol8issue6/E0863140.pdf?id=6097.

Jauhari, D. R. 2018. Gambaran Perilaku Prososial Remaja Pada Siswa Mts. QUANTA STKIP Siliwangi Journals, 2(2): 67-74. DOI: $10.22460 / q$. v2i1p21-30.642.

Juliantika, Y. T., \& Khusumadewi, A. 2017. Penerapan Cinema Therapy Untuk Meningkatkan Empati Siswa Kelas X Multimedia Di SMKN 1 Driyorejo. Jurnal BK Unesa, 7(3): 243-255. Retrieved From https://jurnalmahasiswa.unesa.ac.id/ index.php/jurnal-bkunesa/article/view/21555/19760.

Mirnawati. 2020. Efektifitas Role Playing Dalam Meningkatkan Perilaku Prososial Anak Dengan Hambatan Sosial Emosi. SPECIAL Special and Inclusive Education Journal, 1(1):18-24 DOI: 10.36456/special.vol1.no1.a2169.

Niva, H. 2016. Penerapan Pendekatan Cinematherapy Untuk Meningkatkan Perilaku Prososial Pada Siswa Bosowa International School Makassar. Jurnal
Psikologi Pendidikan \& Konseling, 2(1): 4148. DOI:10.26858/jpkk. v2i1.2061

Padilla-Walker, L. M., Fraser A. M, Black B. B \& Bean R. A. 2014. Associations between friendship, sympathy, and prosocial behavior toward friends. Journal of Research on Adolescence, 25(1): 1-8. https://doi.org/10.1111/jora.12108.

Putra, A. A., Wibowo, M. E., \& Sugiharto, D. Y. P. 2019. The Effectiveness of Group Guidance with Desa Bahagia Game to Improve Students' Prosocial Behaviors. Jurnal Bimbingan Konseling, 8(1): 86-90. DOI:

http://doi.org/10.15294/jubk.v8i1.27904

Putra, H. P., Gustituati, N., \& Syahniar. 2015. Peningkatan Perilaku Prososial Siswa di Sekolah melalui Layanan Bimbingan Kelompok dengan Teknik Modeling. Jurnal Konseling dan Pendidikan, 3(2): 3139. DOI: $10.29210 / 112700$.

Puspita, L., Mulawarman, \& Awalya. 2020. Efektivitas Bimbingan Kelompok Teknik Role Playing untuk Meningkatkan Sikap Empati dan Tanggung Jawab Siswa SMP Negeri 1 Sumowono. Jurnal Fokus Konseling, 6(1):46-53. DOI: DOI: https://doi.org/10.26638/jfk.1167.20 99

Quain, S., Yidana, X. D., Ambotumah, B. B., \& Mensah, I. J. N. A. 2016. Pro-social Behavior amongst Students of Tertiary Institutions: An Explorative and a Quantitative approach. Journal of Education and Practice, 7(9): 26-33. Retrieved Form https://eric.ed.gov/?id=EJ1095830.

Rachman, A., \& Nashori, H. F. 2016. Religiositas dan Perilaku Prososial Pelajar. Unisia Jurnal Ilmu-ilmu Sosial, 38(84): 28-37. Retrieved Form https://journal.uii.ac.id/Unisia/articl e/view/11670/8746.

Rini, A. M. J., \& Sugiharto, D. Y. P. 2017. Pengaruh Layanan Bimbingan Kelompok Terhadap Perilaku Prososial. Indonesian Journal of Guidance and Counseling: Theory 
and Aplicatioan, 6(2): 15-20. DOI 10.15294/IJGC.V6I2.16744.

Sari, B. D. K. R., \& Lianawati, A. 2020. Bimbingan kelompok cinema therapy efektif meningkatkan perilaku prososial pada siswa SMPN 3 Waru. Teraputik: Jurnal Bimbingan dan Konseling, 4(2): 189. 196.

DOI: https://doi.org/10.26539/teraputik.4243 9.

Suwanto, I., \& Nisa, A.T. (2017). Cinema therapy sebagai intervensi dalam konseling kelompok. Seminar \& Workshop Nasional Bimbingan dan Konseling: Jambore Konseling 3 Ikatan Konselor Indonesia (IKI) (pp. 147-152). Pontianak: Ikatan Konselor Indonesia (IKI). Retrieved Form

https://www.gci.or.id/proceedings/v iew_article/204/4/jambore-

konseling-3-2017

Tarmizi, R., Sugiharto, D.Y.P, \& Sutoyo, A. 2020. The Effectiveness of Group Counseling with Self-Management and Cognitive Restructuring Techniques to Reduce Students' Aggression. Jurnal Bimbingan dan Konseling, 10 (1):40-44. DOI: doi.org/10.15294 /jubk v10i1.35373.

Trifiana, R. 2015. Pengaruh Kematangan Emosi Terhadap Perilaku Prososial Remaja Pengguna Gadget di SMP N 2 Yogyakarata. E-Journal Student UNY: Jurnal Riset Mahasiswa Bimbingan dan Konseling, 4(10): 1-13. Retrieved Form http://journal.student.uny.ac.id/ojs/i ndex.php/fipbk/article/view/268.

Wang, M., Wang, J., Deng, X., \& Chen, W. 2019. Why are empathic children more liked by peers? The mediating roles of prosocial and aggressive behaviors. Personality and Individual Differences, 144(2019): 19-23. DOI: 10.1016/j.paid.2019.02.029.

Putra, A. A., Wibowo, M. E., \& Sugiharto, D. Y. P. 2019. The Effectiveness of Group Guidance with Desa Bahagia Game to Improve Students' Prosocial Behaviors. Jurnal Bimbingan Konseling, 8(1): 86-90. DOI:

http://doi.org/10.15294/jubk.v8i1.27904

Vaish, A. 2019. Empathy and Prosocial Behavior. Reference Module in Neuroscience and Biobehavioral Psychology, 441-450. https://doi.org/10.1016/B978-0-12809324-5.21816-6.

Wulandari, T., Dharmayana, I. W., \& Afriyati, V. 2018. Pengaruh Layanan Bimbingan Kelompok Terhadap Perilaku Prososial Siswa Kelas Vii Di Smp Negeri 22 Kota Bengkulu. Consilia Jurnal Ilmiah Bimbingan dan Konseling, 1(2): 76-85. DOI: 10.33369/consilia.1.2.76-85.

Yusuf, P. M., \& Kristiana, I. F. 2017. Hubungan Antara Regulasi Emosi Dengan Perilaku Prososial Pada Siswa Sekolah Menengah Atas. Jurnal Empati: Jurnal Karya Ilmiah S1 Undip, 6 (3): 98 -104. Retrieved Form https://ejournal3.undip.ac.id/index.p hp/empati/article/view/19737. 